\title{
Synthesis, Anticancer and Molecular Docking Studies of 2-(4-chlorophenyl)-5-aryl-1,3,4-Oxadiazole Analogues
}

Mohamed Jawed Ahsan ${ }^{1 *}$, Vikram Pratap Singh Rathod', Monika Singh'1, Ramdayal Sharma', Surender Singh Jadav², Sabina Yasmin ${ }^{2}$, Salahuddin ${ }^{3}$ and Pradeep Kumar ${ }^{1}$

${ }^{1}$ Department of Pharmaceutical Chemistry, Maharishi Arvind College of Pharmacy, Jaipur, Rajasthan 302 023, India

${ }^{2}$ Department of Pharmaceutical Sciences, Birla Institute of Technology, Mesra, Ranchi, Jharkhand 835 215, India

${ }^{3}$ Department of Pharmaceutical Technology, Noida Institute of Engineering and Technology, Knowledge Park II, Greater Noida, Uttar Pradesh 201 306, India

\section{Graphical Abstract}

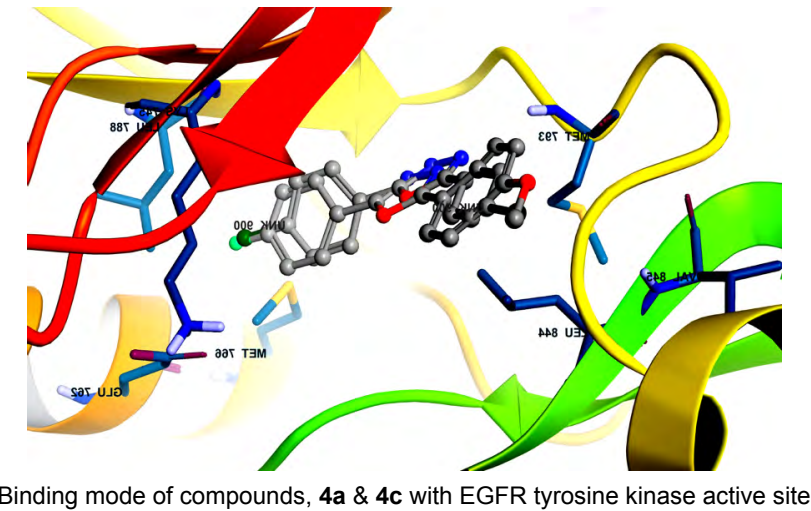

Among a series of ten, 2-(4-chlorophrnyl)-5-aryl-1,3,4-oxadiazole analogs, 4c showed maximum activity on various cancer cell lines, with average growth percent of $95.37 \%$. The molecular docking studies for the compounds 4a \& 4c showed that the residue Cys797 is present near to the para substitution of phenyl group while the five member oxadiazole ring of ligands was lying near to Leu792 and Met 793 of EGFR tyrosine kinase active site.

Keywords: Anticancer; Oxadiazole; Single-dose assay; Molecular docking studies

\section{Introduction}

About 13 percent of all the death worldwide is due to cancer, surpassing cardiovascular disease and taking number one place $[1,2]$. Chemotherapy of cancer is associated with various adverse effects viz. bone marrow depression, alopecia, drug induced caner, etc. and is often associated with cytotoxicity, genotoxicity to normal cells together with the development of resistance [3]. Medicinal chemists have great perseverance in research and development (R \& D) for the search of newer and safer anticancer agents. EGFR family of Tyrosine Kinases (TK) play a vital role in cancer proliferation and it is suggested that any agent which would inhibit the TK activity may have substantial role in the cancer treatment [4]. So we selected EGFR family of TK and explore the binding mode of the our compounds to EGFR tyrosine kinase active site. Imatinib (gleevec) an anticancer drug is TK inhibitor (TKI), inhibits TK encoded by the bcr-abl oncogene as well as receptor TKs encoded by the c-kit and platelet-derived growth factor receptor (PDGFR) oncogenes [5]. Oxadiazole derived compounds are known to display wide range of biological and pharmacological activities including anticancer, antitubercular, antibacterial, antifungal, antiHIV, anti-inflammatory, and insecticidal activities [6-12]. There are nearly 2577 publications from 2002 to 2012 involving 1,3,4-oxadiazoles [13]. Some of the marketed oxadiazole drugs include raltegravir (antiretroviral), zibotentan (anticancer), etc. We have earlier reported the anticancer activity of some novel oxadiazole analogues $[6,14]$.

\section{Materials and Methods}

\section{Chemistry}

All chemicals were supplied by E. Merck, and S. D. Fine Chemicals.
Melting points were determined by open tube capillary method and are uncorrected. Purity of the compounds was checked by elemental analysis and the progress of reactions was monitored by TLC plates (silica gel G) using mobile phase, chloroform: methanol (9:1), and acetone: $n$-hexane (8:2) and the spots were identified by iodine vapours or UV light. IR spectra were recorded on a Schimadzu 8201 PC, FTIR spectrometer ( $\mathrm{KBr}$ pellets). $1 \mathrm{H}$ NMR spectra were recorded on a Bruker AC $300 \mathrm{MHz}$ spectrometer using TMS as internal standard in DMSO d6. Mass spectra were recorded on a Bruker Esquire LCMS using ESI and elemental analyses were performed on Perkin-Elmer 2400 Elemental Analyzer.

General method for the synthesis of 4-chlorobenzohydrazide (3): 4-Chlorobenzoic acid (1) (7.84 g, $0.05 \mathrm{~mol})$ was dissolved in excess of ethanol $(50 \mathrm{ml})$ the reaction mixture was acidified and refluxed for 8-10 $\mathrm{h}$. The layer of ester is separated by filtration flask and neutralized with sodium bicarbonate to obtain ethyl-4-chlorobenzoate (2). Equimolar mixture of ethyl-4-chlorobenzoate (2) and hydrazine hydrate was

*Corresponding author: Mohamed Jawed Ahsan, Department of Pharmaceutical Chemistry, Maharishi Arvind College of Pharmacy, Jaipur, Rajasthan 302 023, India Tel: +91 9694087786; Fax: +91 144; E-mail: jawedpharma@gmail.com

Received November 19, 2013; Accepted December 19, 2013; Published December 21, 2013

Citation: Ahsan MJ, Singh Rathod VP, Singh M, Sharma R, Jadav SS, et al. (2013) Synthesis, Anticancer and Molecular Docking Studies of 2-(4-chlorophenyl)-5 aryl-1,3,4-Oxadiazole Analogues. Med chem 3: 294-297. doi:10.4172/21610444.1000154

Copyright: $\odot 2013$ Ahsan MJ, et al. This is an open-access article distributed under the terms of the Creative Commons Attribution License, which permits unrestricted use, distribution, and reproduction in any medium, provided the original author and source are credited. 
refluxed for $12 \mathrm{~h}$ and the excess solvent removed under vacuum and poured into the crushed ice to obtain 4-chlorobenzohydrazide (3).

General method for the synthesis of 2-(4-chlorophenyl)-5-aryl1,3,4-oxadiazole analogues(4a-j): 4-Chlorobenzohydrazide $(0.85 \mathrm{~g}$, $0.005 \mathrm{~mol}$ ) (3) and aromatic aldehydes was refluxed 10-12 h using 20 mol\% NaHSO3 and ethanol-water system (1:2, v/v) solvent [15]. After completion of reaction the mixture the excess solvent removed and the concentrate was poured into crushed ice washed with water, dried and recrystallized with absolute ethanol. The reaction was monitored throughout by TLC using chloroform-methanol (9:1) and acetone: n-hexane (8:2) as mobile phase.

2-(4-Chlorophenyl)-5-(4-fluorophenyl)-1,3,4-oxadiazole (4a) Yield 70\%, IR (KBr) 1521, 1112, 789, $745 \mathrm{~cm}-1 ; 1 \mathrm{H}$ NMR $(300 \mathrm{MHz}$, DMSO-d6): $\delta$ 7.02-7.03 (2H, d, $J=3.2 \mathrm{~Hz}, \mathrm{ArH}), 7.36-7.38(2 \mathrm{H}, \mathrm{d}, J=6.1$ $\mathrm{Hz}, \mathrm{ArH}), 7.39-7.41(2 \mathrm{H}, \mathrm{d}, J=6.0 \mathrm{~Hz}, \mathrm{ArH}), 7.43-7.45(2 \mathrm{H}, \mathrm{d}, J=6.2 \mathrm{~Hz}$, ArH). 13C NMR (75 MHz, DMSO-d6): $\delta 116.1,121.9,124.5,128.7$, 129.2, 129.7, 134.7, 162.6, 164.8; $\mathrm{m} / \mathrm{z}=274(\mathrm{M}+), 275(\mathrm{M}+1)+1,276$ $(\mathrm{M}+2)+$. Cal/Ana: [C (61.12) $61.22 \mathrm{H}(2.92) 2.94 \mathrm{~N}(10.08) 10.20]$.

2-(4-Chlorophenyl)-5-(4-chlorophenyl)-1,3,4-oxadiazole (4b) Yield 74\%, IR (KBr) 1531, 1131, $742 \mathrm{~cm}-1 ; 1 \mathrm{H}$ NMR $(300 \mathrm{MHz}$ DMSO- $d 6): \delta 7.28-7.30(4 \mathrm{H}, \mathrm{dd}, J=6.1 \mathrm{~Hz} \mathrm{ArH}), 7.39-7.41(4 \mathrm{H}, \mathrm{dd}$, $J=6.2 \mathrm{~Hz} \mathrm{ArH}) ; m / z=290(\mathrm{M}+), 292(\mathrm{M}+2)+. \mathrm{Cal} /$ Ana: [C (57.62) 57.76 $\mathrm{H}(2.79) 2.77 \mathrm{~N}$ (9.59) 9.62].

2-(4-Chlorophenyl)-5-(4-methoxyphenyl)-1,3,4-oxadiazole (4c) Yield 82\%, IR (KBr) 1526, 1121, $749 \mathrm{~cm}-1 ; 1 \mathrm{H}$ NMR $(300 \mathrm{MHz}$, DMSO-d6): $\delta 3.79$ (3H, s, OCH3), 7.32-7.34 (2H, d, $J=6.1 \mathrm{~Hz}, \mathrm{ArH})$, 7.35-7.37 $(2 \mathrm{H}, \mathrm{d}, J=6.1 \mathrm{~Hz}, \operatorname{ArH}), 7.39-7.41(2 \mathrm{H}, \mathrm{d}, J=6.0 \mathrm{~Hz}, \mathrm{ArH})$, 7.81- $7.83(2 \mathrm{H}, \mathrm{d}, J=6.1 \mathrm{~Hz} \mathrm{ArH}) ; m / z=286(\mathrm{M}+), 288(\mathrm{M}+2)+. \mathrm{Cal} /$ Ana: [C (62.79) 62.84 H (3.89) 3.87 N (9.57) 9.77].

2-(4-Chlorophenyl)-5-(3,4-dimethoxyphenyl)-1,3,4-oxadiazole (4d) Yield 79\%, IR (KBr) 1528, 1127, $694 \mathrm{~cm}-1$; 1H NMR (300 MHz, DMSO-d6): $\delta 3.81(6 \mathrm{H}, \mathrm{s}, \mathrm{OCH} 3), 7.31-7.33(2 \mathrm{H}, \mathrm{d}, J=6.1 \mathrm{~Hz}, \mathrm{ArH})$, 7.42-7.44 (2H, d, $J=6.2 \mathrm{~Hz}, \operatorname{ArH}), 7.89-7.92(3 \mathrm{H}, \mathrm{m}, \mathrm{ArH}) ; m / z=316$ $(\mathrm{M}+), 318(\mathrm{M}+2)+$. Cal/Ana: [C (60.47) $60.67 \mathrm{H}(4.19) 4.14 \mathrm{~N}(8.77)$ 8.84].

2-(4-Chlorophenyl)-5-(4-hydroxy-3-methoxyphenyl)-1,3,4oxadiazole (4e) Yield 65\%, IR (KBr) 3397, 1525, 1132, $699 \mathrm{~cm}-1 ; 1 \mathrm{H}$ NMR (300 MHz, DMSO-d6): $\delta 3.83(3 \mathrm{H}, \mathrm{s}, \mathrm{OCH} 3), 7.31-7.33(2 \mathrm{H}, \mathrm{d}$, $J=6.0 \mathrm{~Hz}, \mathrm{ArH}), 7.42-7.44(2 \mathrm{H}, \mathrm{d}, J=6.1 \mathrm{~Hz}, \mathrm{ArH}), 7.84-7.87(3 \mathrm{H}, \mathrm{m}$, $\mathrm{ArH}), 10.27(1 \mathrm{H}, \mathrm{s}, \mathrm{OH}) ; m / z=302(\mathrm{M}+), 304(\mathrm{M}+2)+\mathrm{Cal} / \mathrm{Ana}:[\mathrm{C}$ (59.47) $59.52 \mathrm{H}(3.59) 3.66 \mathrm{~N}(9.22) 9.25]$.

2-(4-Chlorophenyl)-5-(2-hydroxyphenyl)-1,3,4-oxadiazole (4f) Yield 81\%, IR (KBr) 3409, 1521, 1271, $697 \mathrm{~cm}-1$; 1H NMR $(300 \mathrm{MHz}$, DMSO- $d 6): \delta 7.33-7.35(2 \mathrm{H}, \mathrm{d}, J=6.0 \mathrm{~Hz}, \mathrm{ArH}), 7.41-7.43(2 \mathrm{H}, \mathrm{d}, J=6.1$ $\mathrm{Hz}, \mathrm{ArH}), 7.81-7.84(3 \mathrm{H}, \mathrm{m}, \mathrm{ArH}), 10.02(1 \mathrm{H}, \mathrm{s}, \mathrm{OH}) ; \mathrm{m} / z=272(\mathrm{M}+)$, $274(\mathrm{M}+2)+. \mathrm{Cal} / \mathrm{Ana}$ : [C (66.57) $61.66 \mathrm{H}(3.39) 3.33 \mathrm{~N}$ (10.25) 10.27].

2-(4-Chlorophenyl)-5-(4-hydroxyphenyl)-1,3,4-oxadiazole (4g) Yield 80\%, IR (KBr) 3401, 1527, 1121, $699 \mathrm{~cm}-1$; 1H NMR $(300 \mathrm{MHz}$, DMSO-d6): $\delta$ 6.79-6.81 (2H, s, ArH), 7.27-7.29m $(2 \mathrm{H}, \mathrm{d}, J=6.0 \mathrm{~Hz}$, $\operatorname{ArH}), 7.34-7.36(2 \mathrm{H}, \mathrm{d}, J=6.0 \mathrm{~Hz}, \operatorname{ArH}), 7.41-7.43(2 \mathrm{H}, \mathrm{d}, J=6.1 \mathrm{~Hz}$, $\mathrm{ArH}), 7.81-7.84(3 \mathrm{H}, \mathrm{m}, \mathrm{ArH}), 10.12(1 \mathrm{H}, \mathrm{s}, \mathrm{OH}) ; m / z=302(\mathrm{M}+), 304$ $(\mathrm{M}+2)+$. Cal/Ana: [C (59.45) $59.52 \mathrm{H}(3.65) 3.66 \mathrm{~N}(9.28)$ 9.25].

2-(4-Chlorophenyl)-5-phenyl-1,3,4-oxadiazole (4h) Yield 66\%, IR (KBr) 1529, 1137, $702 \mathrm{~cm}-1$; 1H NMR (300 MHz, DMSO-d6): $\delta$ 7.31$7.33(2 \mathrm{H}, \mathrm{d}, J=6.0 \mathrm{~Hz}, \mathrm{ArH}), 7.41-7.43(2 \mathrm{H}, \mathrm{d}, J=6.1 \mathrm{~Hz}, \mathrm{ArH}), 7.67-$ $7.71(5 \mathrm{H}, \mathrm{m}, \mathrm{ArH}) ; m / z=256(\mathrm{M}+), 258(\mathrm{M}+2)+. \mathrm{Cal} / \mathrm{Ana}:$ [C (65.47) $65.51 \mathrm{H}(3.59) 3.53 \mathrm{~N}(10.82) 10.91]$.
2-(4-Chlorophenyl)-5-(4-methylphenyl)-1,3,4-oxadiazole Yield 13\%, IR (KBr) 1519, 1139, $714 \mathrm{~cm}-1$; $1 \mathrm{H}$ NMR $(300 \mathrm{MHz}$ DMSO-d6): $\delta 2.32(3 \mathrm{H}, \mathrm{s}, \mathrm{CH} 3), 7.14-7.16(2 \mathrm{H}, \mathrm{d}, J=6.0 \mathrm{~Hz}, \mathrm{ArH})$, 7.32-7.34 $(2 \mathrm{H}, \mathrm{d}, J=6.1 \mathrm{~Hz}, \operatorname{ArH}), 7.35-7.37(2 \mathrm{H}, \mathrm{d}, J=6.0 \mathrm{~Hz}, \mathrm{ArH})$, 7.41- $7.43(2 \mathrm{H}, \mathrm{d}, J=6.0 \mathrm{~Hz}, \mathrm{ArH}) ; m / z=270(\mathrm{M}+), 272(\mathrm{M}+2)+. \mathrm{Cal} /$ Ana: [C (66.47) $66.55 \mathrm{H}(4.19) 4.10 \mathrm{~N}$ (10.31) 10.35].

2-(4-Chlorophenyl)-5-(furan-2-yl)-1,3,4-oxadiazole (4j) Yield 69\%, IR (KBr) 1525, 1124, $731 \mathrm{~cm}-1$; 1 H NMR (300 MHz, DMSO-d6): $\delta$ 6.98-7.01 (3H, s, Furan), 7.32-7.34 (2H, d, J=6.0 Hz, ArH), 7.39-7.41 $(2 \mathrm{H}, \mathrm{d}, J=6.1 \mathrm{~Hz}, \mathrm{ArH}) ; m / z=246(\mathrm{M}+), 248(\mathrm{M}+2)+$. Cal/Ana: [C (58.37) $58.43 \mathrm{H}(2.81) 2.86 \mathrm{~N}$ (11.32) 11.36].

\section{Anticancer activity}

The compounds ( $4 \mathrm{a}$ and $4 \mathrm{c}$ ) submitted to the NCI 60 cell screen were tested initially at a single high dose (10-5 M) on leukemia, melanoma, lung, colon, CNS, ovarian, renal, prostate, and breast cancers cell lines, nearly 60 in number. The one-dose data was reported as a mean graph of the percent growth of treated cells. The number reported for the onedose assay is growth relative to the no-drug control, and relative to the time zero number of cells. The anticancer screening was carried out as per the NCI US protocol reported elsewhere [16-19]. We have discussed the anticancer screening method in our previous work $[6,14,20]$.

\section{Molecular docking studies}

$\mathrm{X}$-ray crystal structure of EGFR tyrosine kinase (PDB: 2J5F) was downloaded from www.rcsb.org. The active site of $2 \mathrm{~J} 5 \mathrm{~F}$ is well established with hydrophobic active site containing irreversible inhibitor and molecular docking simulations were performed in order to distinguish the basic receptor-ligand interactions. The X-ray crystal structure of EGFR tyrosine kinase domain had the resolution of $3.00 \AA$. The protein was prepared by using the Protein Preparation Wizard, pre-processed and heterostate for co-crystallized ligand was generated using Epik; protonation state and optimization of $\mathrm{H}$ bonding of the protein side chains were assigned using Protassign, energy minimized (impref minimization) using OPLS2001 force field. Receptor grid has been prepared with default parameters and without any constrains. Site was specified around the reference ligands $\mathrm{N}$-[4(3- bromophenylamino)quinazolin-6-yl]acrylamide of EGFR tyrosine kinase. The three dimensional structures of ligands were drawn by using the Maestro 8.5. The ligands were prepared by using Ligprep utility of Schrodinger Suite with default parameters, the ligand energy minimized by using OPLS 2005 (Macromodel multiple minimization) and water as solvent. The ligands did not show the formation of any tautomers or isomers after ligprep and macromodel multiple energy minimizations. The ligands' docking was performed with Xtra precision mode (XP) which is employed in GLIDE 5.0 module implemented in the Schrodinger LLC.

\section{Results and Discussion}

\section{Chemistry}

In the first step 4-chlorobenzoic acid (1) in excess of ethanol was refluxed for 8-10 h in acidic medium to obtain ethyl-4-chlorobenzoate (2). In the subsequent step compound (2) was refluxed with hydrazine hydrate in ethanol for $12 \mathrm{~h}$ to obtain 4-chlorobenzohydrazide (3). In the final step 4-chlorobenzohydrazide (3) and aromatic aldehydes was refluxed 10-12 h using 20 mol\% NaHSO3 and ethanol-water system $(1: 2, v / v)$ solvent to obtain oxadiazole analogues $(4 a-n)$. The reaction was monitored throughout by thin layer chromatography (TLC) using chloroform-methanol (9:1) and acetone: $\mathrm{n}$-hexane (8:2) as mobile phase 
and the purity of the compounds was checked by elemental analysis. The reaction sequence is shown in Scheme 1. The synthesized compounds were characterized by spectral analysis and all the compounds were in full harmony with the proposed structures. In general the IR spectra afforded absorption 1519-1531 cm-1 band due to $\mathrm{C}=\mathrm{N}$ and 1112 $1271 \mathrm{~cm}-1$ due to oxadiazole stretching. In $1 \mathrm{H}$ NMR the signals of the respective protons of the synthesized title compounds were verified on the basis of their chemical shifts and multiplicities in DMSO d6. The spectra showed a singlet at $\delta 3.79-3.83 \mathrm{ppm}$ corresponding to $\mathrm{OCH} 3$; a doublet or multiplet at $\delta 6.79-7.92 \mathrm{ppm}$ corresponding to aromatic protons.

\section{Anticancer activity}

2-(4-chlorophenyl)-5-(4-fluorophenyl)-1,3,4-oxadiazole showed growth percent (GP) of 87.27 (SF-295; CNS cancer) and 89.12 (MCF7; Brest Cancer) while 2-(4- chlorophenyl)-5-(4-methoxyphenyl)1,3,4-oxadiazole (4c) showed GP of 71.70 (PC-3; Prastate cancer) and 74.14 (SR; Leukemia). The compound 4c (mean GP; 95.37) was found to be more active than the compound 4a (mean GP; 98.74). The in vitro anticancer activity of the compounds is given in Table 1 . The compound $4 \mathrm{c}$ with 4 -methoxyphenyl at the 5 position of the oxadiazole ring showed more anticancer activity than the compound 4a with 4 -fluorophenyl at the 5 position of oxadiazole nucleus.

\section{Molecular docking studies}

The EGFR tyrosine kinase was reported several times as target for the inhibition of cancer cells. It contains the bound ligand $\mathrm{N}$-[4(3-bromophenylamino) quinazolin-6-yl] acrylamide and is well established by the presence of hydrophobic cavity at active site. Redocking of bound or reference ligand 34-JAB with EGFR tyrosine kinase exhibited the hydrophobic interactions with the residues Thr790, Met793 and Cys797. The amino acid residues Lys745, Glu762, Met766, Leu788, Met793 and Thr854 make the receptor hydrophobic in nature. The most important residue Cys797 is present near to the para substitution of phenyl group. The five member oxadiazole ring of ligands was lying near to Leu792 and Met 793. It was observed that the presence of methoxy functional group at para position may become more selective towards the EGFR tyrosine kinase [14]. In order to predict the binding affinity and pre eminent docked structures, the combined ligand docking and energy-grid scores were ranked by using E model and Glide scores. The ligand docking and E model scores were provided in the Table 2 . The docking scores of compounds $4 \mathrm{a}$ and $4 c$ were -5.251 and -5.433 respectively. The molecular docking and binding of ligands $4 \mathrm{a}$ and $4 \mathrm{c}$ is shown in Graphical abstract, while the $2 \mathrm{D}$ pose of the ligand $4 \mathrm{c}$ and the active site EGFR tyrosine kinase is shown in Figures 1 and 2.

\section{Conclusion}

A series of 10 oxadiazole analogues were synthesized in satisfactory yield and two compounds were evaluated for their in vitro anticancer activity at single-dose assay. The oxadiazole analogues showed moderate anticancer activity on various cell lines and molecular docking studies showed that the residue Cys797 is present near to the para substitution of phenyl group while the five member oxadiazole ring of ligands was lying near to Leu792 and Met 793 of EGFR tyrosine kinase active site. The oxadiazole analogues reported in this study may be further modified to increase their anticancer activity.

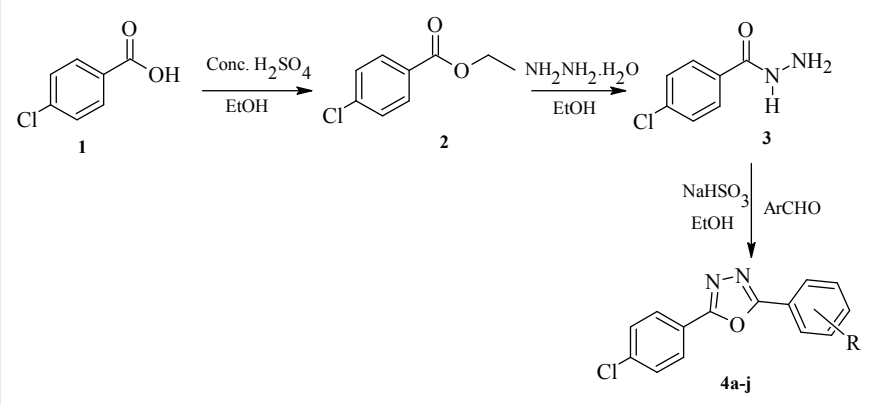

Scheme 1: Protocol for the synthesis of 2-(4-chloro)-5-aryl-1,3,4-oxadiazole analogues (4a-j).

\begin{tabular}{|c|c|c|c|c|c|}
\hline \multirow[t]{2}{*}{ Comp. } & \multicolumn{5}{|c|}{60 cell lines assay in 1 dose $10^{-5} \mathrm{M}$ conc. } \\
\hline & $\begin{array}{l}\text { NSC } \\
\text { Code }\end{array}$ & $\begin{array}{l}\text { Mean } \\
\text { GP }\end{array}$ & $\begin{array}{l}\text { Range } \\
\text { of GP }\end{array}$ & $\begin{array}{l}\text { The most sensitive cell } \\
\text { line }\end{array}$ & $\begin{array}{l}\text { GP of the most } \\
\text { sensitive cell line }\end{array}$ \\
\hline \multirow{5}{*}{$4 a$} & \multirow{5}{*}{776718} & \multirow{5}{*}{98.74} & \multirow{5}{*}{$\begin{array}{l}87.26 \text { to } \\
112.87\end{array}$} & SF-295 (CNS Cancer) & 87.26 \\
\hline & & & & MCF7 (Brest Cancer) & 89.12 \\
\hline & & & & UO-31 (Renal Cancer) & 89.93 \\
\hline & & & & HCT-15 (Colon cancer) & 90.55 \\
\hline & & & & $\begin{array}{l}\mathrm{NCl}-\mathrm{H} 522 \text { (Non-Small } \\
\text { Cell Lungs cancer) }\end{array}$ & 91.27 \\
\hline \multirow{5}{*}{ 4c } & \multirow{5}{*}{776717} & \multirow{5}{*}{95.37} & \multirow{5}{*}{$\begin{array}{l}71.70 \text { to } \\
110.76\end{array}$} & PC-3 (Prostate Cancer) & 71.70 \\
\hline & & & & SR (Leukemia) & 74.14 \\
\hline & & & & UO-31 (Renal Cancer) & 80.62 \\
\hline & & & & $\begin{array}{l}\mathrm{NCl}-\mathrm{H} 522 \text { (Non-Small } \\
\text { Cell } \\
\text { Lungs cancer) }\end{array}$ & 82.58 \\
\hline & & & & $\begin{array}{l}\text { SK-OV-3 (Ovarian } \\
\text { Cancer) }\end{array}$ & 83.34 \\
\hline
\end{tabular}

Table 1: Anticancer activity of the selected oxadiazole analogues.

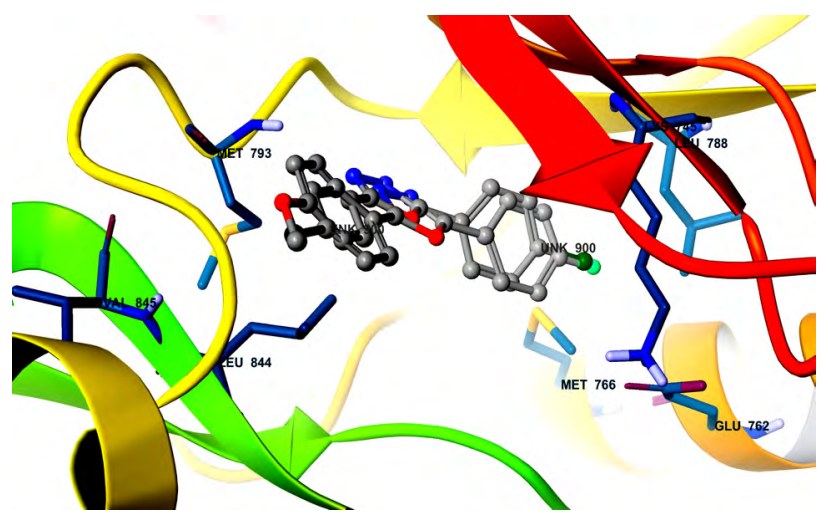

Figure 1: Superimposed diagram of the two ligands $4 \mathrm{a}$ and $\mathbf{4 c}$ (ball and stick model).
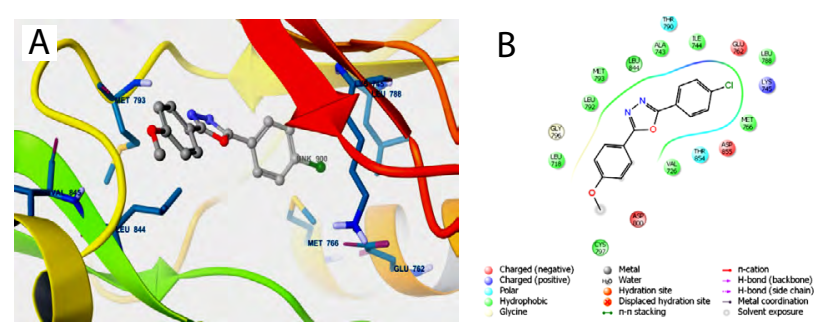

Figure 2: (A) ligand 4c was shown in ball and stick model and remaining were EGFR tyrosine kinase active site residues; (B) 2D pose view diagram of the ligand 4c and EGFR tyrosine kinase active site residues. 
Citation: Ahsan MJ, Singh Rathod VP, Singh M, Sharma R, Jadav SS, et al. (2013) Synthesis, Anticancer and Molecular Docking Studies of 2-(4-chlorophenyl)-5-aryl-1,3,4-Oxadiazole Analogues. Med chem 3: 294-297. doi:10.4172/2161-0444.1000154

\begin{tabular}{|l|l|l|l|}
\hline S. No. & Compound & Docking score & E-model score \\
\hline 1 & Reference [21] & -8.288 & -68.491 \\
\hline 2 & 4a & -5.251 & -37.778 \\
\hline 3 & 4c & -5.433 & -38.804 \\
\hline
\end{tabular}

Table 2: The docking score and $E$ model score of reference ligand and selected ligands $(4 \mathrm{a}$ and $\mathbf{4 c})$.

The authors confirm that this article content has no conflicts of interest.

\section{Acknowledgments}

Anticancer data were provided by National Cancer Institute, Bethesda, MD USA. We are grateful for all help provided by Prof. Doug Smallwood and Dr. Mohammed Nayel. The management of Maharishi Arvind College of Pharmacy, Jaipur, Rajasthan, India is acknowledged for providing research facilities.

\section{References}

1. WHO, Cancer, World Health Organization, February 2006.

2. Noolvi MN, Patel HM, Bhardwaj V, Chauhan A (2011) Synthesis and in vitro antitumor activity of substituted quinazoline and quinoxaline derivatives: search for anticancer agent. Eur J Med Chem 46: 2327-2346.

3. Aydemir N, Bilaloğlu R (2003) Genotoxicity of two anticancer drugs, gemcitabine and topotecan, in mouse bone marrow in vivo. Mutat Res 537: 43-51.

4. Mendelsohn J, Baselga J (2000) The EGF receptor family as targets for cancer therapy. Oncogene 19: 6550-6565.

5. http://www.cancer.gov/drugdictionary?cdrid=37862

6. Salahuddin, Shaharyar M, Majumdar A, Ahsan MJ (2013) Synthesis, characterization and anticancer evaluation of 2-(Naphthalen-1-ylmethyl/ Naphthalen-2-yloxymethyl)- 1-[5-(substituted phenyl)-[1, 3, 4] oxadiazol-2ylmethyl]-1H-benzimidazole. Arab J Chem (In press).

7. Ahsan MJ, Samy JG, Khalilullah H, Nomani MS, Saraswat P, et al. (2011) Molecular properties prediction and synthesis of novel 1,3,4-oxadiazole analogues as potent antimicrobial and antitubercular agents. Bioorg Med Chem Lett 21: 7246-7250.

8. Ahsan MJ, Samy GJ, Jain CB, Dutt KR, Khalilullah H, Nomani MS (2012) Discovery of novel antitubercular 1,5-dimethyl-2-phenyl-4-(\{[5-(arylamino)1,3,4-oxadiazol-2-yl]methyl\}amino)-1,2-dihydro-3H-pyrazol-3-one analogues. Bioorg Med Chem Lett 21: 969-972.

9. Bakht MA, Yar MS, Abdel-Hamid SG, Al Qasoumi SI, Samad A (2010) Molecular properties prediction, synthesis and antimicrobial activity of some newer oxadiazole derivatives. Eur J Med Chem 45: 5862-5869.

10. Akhtar T, Hameed S, Al-Masoudi NA, Loddo R, La Colla $P$ (2008) In vitro antitumor and antiviral activities of new benzothiazole and 1,3,4-oxadiazole-2thione derivatives. Acta Pharm 58: 135-149.

11. Ramaprasad GC, Kalluraya B, Kumar S, Mallaya S (2013) Synthesis of new oxadiazole derivatives as anti-inflammatory, analgesic, and antimicrobial agents. Med Chem Res 22: 5381-5389.

12. Li Y, Zhu H, Chen K, Liu R, Khallaf A, et al. (2013) Synthesis, insecticidal activity, and structure-activity relationship (SAR) of anthranilic diamides analogs containing oxadiazole rings. Org Biomol Chem 11: 3979-3988.

13. de Oliveira CS, Lira BF, Barbosa-Filho JM, Lorenzo JG, de Athayde-Filho PF (2012) Synthetic approaches and pharmacological activity of 1,3,4-oxadiazoles: a review of the literature from 2000-2012. Molecules 17: 10192-10231.

14. Ahsan MJ, Sharma J, Bhatia S, Goyal PK, Shankhala K, et al. (2014) Synthesis of 2,5-disubstituted-1,3,4-oxadiazole analogs as novel anticancer and antimicrobial agents. Lett Drug Des Dis (In press).

15. Sangshetti JN, Chabukswar AR, Shinde DB (2011) Microwave assisted one pot synthesis of some novel 2,5-disubstituted 1,3,4-oxadiazoles as antifungal agents. Bioorg Med Chem Lett 21: 444-448.

16. Le Cam A, Bobe J, Bouchez O, Cabau C, Kah O, et al. (2012) Characterization of rainbow trout gonad, brain and gill deep cDNA repertoires using a Roche 454-Titanium sequencing approach. Gene 500: 32-39.

17. Monks A, Scudiero D, Skehan P, Shoemaker R, Paull K, et al. (1991) Feasibility of a high-flux anticancer drug screen using a diverse panel of cultured human tumor cell lines. J Natl Cancer Inst 83: 757-766.

18. Boyd MR, Paull KD (1995) Some practical considerations and applications of the National Cancer Institute in vitro anticancer drug discovery screen. Drug Dev Res 34:91-109.

19. Shoemaker $\mathrm{RH}$ (2006) The $\mathrm{NCl} 60$ human tumour cell line anticancer drug screen. Nat Rev Cancer 6: 813-823.

20. Ahsan MJ, Khalilullah H, Yasmin S, Jadav SS, Govindasamy J (2013) Synthesis, characterisation, and In Vitro anticancer activity of curcumin analogues bearing pyrazole/pyrimidine ring targeting EGFR tyrosine kinase. BioMed Res Int 2013 239354.

21. Blair JA, Rauh D, Kung C, Yun CH, Fan QW, et al. (2007) Structure-guided development of affinity probes for tyrosine kinases using chemical genetics. Nat Chem Biol 3: 229-238. 